\title{
Topographies of Defeat
}

\author{
By Asbjørn Grønstad
}

Fall 2001 Issue of KINEMA

\section{TOPOGRAPHIES OF DEFEAT: MASCULINITY AND DESOLATION IN FAT CITY AND JUNIOR BONNER}

\author{
Success stories, per se, are not really of much interest to me \\ (John Huston)
}

In 1972, two of Hollywood's most independent filmmakers -- John Huston and Sam Peckinpah -- directed two pensive, deceptively inconspicuous movies which probed the existential malaise afflicting a particular form of American masculinity. Fat City ${ }^{(1)}$-- Huston's first American film in more than a decade -- was released to much critical acclaim, and reviewers came to rank it alongside his best previous efforts like The Maltese Falcon (1941), The Treasure of the Sierra Madre (1948), The Asphalt Jungle (1950) and The African Queen (1951). ${ }^{(2)}$ Commercially, however, it was a modest failure. ${ }^{(3)}$ With Junior Bonner, Peckinpah thoroughly defied the anticipations of critics and spectators who expected (and craved?) another cinematic blood orgy like the one in The Wild Bunch (1969), or in his previous and supremely infamous film Straw Dogs (1971). The Steve McQueen-fronted follow-up to Peckinpah's most controversial film was a slow, somewhat contemplative and leisurely paced picture, virtually free of the violence with which his name had been inextricably linked in the past. It was therefore disappointing that Junior Bonner was almost completely neglected by contemporary critics. ${ }^{(4)}$ Even without the violence, the film rehearses themes quintessential to the Peckinpah oeuvre, marking Junior Bonner as a modern-day western. Attempting to redress the poverty of critical attention that these two films received, I propose in this essay to explore the following hypothesis: Fat City and Junior Bonner are films whose fundamental preoccupation is the generation of images of male desolation. While the former narrates a cynical and wholly un-sentimental tale of urban decay and masculine plight, the latter retreats into an insurmountable nostalgia for the past which ultimately severs its relations to contemporary concerns. Because of this, Fat City prevails as the film whose vision retains hope despite the seeming hopelessness of its environment. Junior Bonner, on the other hand, wallows in the process of mourning the passing of old values and has thus little to offer, or invest, in the social transition from the "Old" to the "New" West. Furthermore, the cinematic styles of the two movies, though apparently similar on the surface, represent radically different approaches to the construction of film narrative. Huston's text is a model of screen naturalism, ${ }^{(5)}$ whereas Peckinpah's continues the project of The Wild Bunch of (violently) fragmenting and dissolving the continuity of story space.

In this essay, I want to investigate the extent to which the protagonists in the two films may be seen as both reflections and extensions of the grim spatial and environmental context of which they are a part. The specific configurations of film space -- urban/suburban in Fat City, rural in Junior Bonner -- are, I argue, indexes of the emotional and psychological impasse of the characters. In their immobility, Tully and Bonner also fail profoundly as narrative agents; their inability to change or to enhance their existential conditions actually obstructs story progression. In this sense, Huston and Peckinpah have made films that violate one of the most indispensable components of classical Hollywood filmmaking: the active protagonist pursuing a specific objective the quest for which dramaturgically validates the narrative movement. On this account it is perfectly viable to consider these two movies that exhibit closer affinities with the European art film than with the classical American tradition.

Fat City and Junior Bonner are anomalous texts in their ideological deviation from standard scenarios that involve the successfully completed ordeals of rugged, independent male heroes. Essentially, Huston's and Peckinpah's films are studies in masculine defeatism, and as such they exude -- both politically and narratively -- an aura of "un-Americanness." ${ }^{(6)}$ This aspect becomes even more pronounced when we take into account the respective activities pursued by the protagonists: rodeo -- with "its echoes of a debased Western heroism" (Andrews, 1973: 73) -- and boxing represent arenas that are vitally infused with an aggressive male sensibility. ${ }^{(7)}$ As spectacles of the male body, they are ritualistically constitutive of a richly valued American masculinity. Moreover, in these arenas defeat is generally not an option. Particularly 
within popular media representations of rodeo and boxing matches, the portrayal of losers is virtually an illicit subject. Hence, audiovisual fictions that zero in on losers are in a certain sense subversive already in their choice of subject matter. The scope of this aberration is also underscored by Gaylyn Studlar, who claims that "the relevance of his [Huston's] films' self-evident fascination with failed masculinity to a theoretical consideration of the spectatorial pleasures to be derived from Hollywood's representation of men" is still an underdeveloped research area (Studlar, 1993: 182). I do not claim that Fat City and Junior Bonner are exceptional movies in the history of American cinema, but they do seem to be somewhat atypical with respect to their generic affiliation. The characters of Tully and Bonner are perhaps as related to film noir's depiction of the maladjusted male as they are to later genre films like, say, Rocky (John G. Avildsen 1976) or The Electric Horseman (Sidney Pollack 1979). Both Fat City and Junior Bonner were shot on location $^{(8)}$-- Huston's film in Stockton, California, Peckinpah's in Prescott, Arizona -- and the images that constitute the narratives are thus infused with a particular social imaginary (Klein, 1998: 85) which works to re-define cinematic space as a protagonist in itself, and not simply as dramatic background. The fact that the movies were shot on location does nothing to promote a simple naturalism. ${ }^{(9)}$ Although critics tend to describe Huston's style as documentary-like, ${ }^{(10)}$ there is no simple equation between the actual Stockton and the filmic Stockton. This is because the process of capturing space on film implies a whole range of technical, aesthetic and narrative transformations, the specifics of which we do not have time to deal with in this context. Suffice it to say, as Norman M. Klein has put it, that "movies, by definition, will fictionalize any location where they are shot" (Klein, 1998: 91) and "Filmmakers...have to be vampires of the location they shoot" (Klein, 1998: 96). This implies that the ontology of a certain chunk of real, existing space is irretrievably altered once the cameras start rolling. But the relation between the profilmic and the filmic runs in the opposite direction as well. That is, architectural space is rarely simply a background against which the narrative action takes place; it is a narrational presence in its own right. Invoking a similar idea, Robert Mallet-Stevens, the art director for Marcel L'Herbier's 1924 film The New Enchantment, once stated that "Modern architecture does not just offer cinematographic decor, it leaves its imprint on the mise en scène" (Matheou, 1994: 28). Since the topography of the location is also subject to a narrative treatment, the mise-en-scene inevitably becomes something more than mere embellishment. Spatial location, however, infrequently attains something close to the status of protagonist, or narrative agent. Finally, in actively involving the mise-en-scene in this manner, the directors manage to convey fundamentally introspective states of consciousness in purely visual, cinematic terms. What Huston and Peckinpah reconfirm in these remarkably low-key, unostentatious films is their reputation as the perhaps most visually literate filmmakers in American Cinema.

Before we turn to consider the Huston text, a brief inspection of the nature of profilmic Stockton may be in order. A city that celebrates its 150th anniversary in 2000, Stockton was founded by German immigrant Charles M. Webb as a gold-rush camp. Due to its location at the end of a 78-mile long navigable channel which connects it with the San Francisco Bay Area -- as well as to the introduction of irrigation -- the city soon prospered as an important inland shipping port and a major agricultural centre. In more recent times, the construction of the cross-town freeway has allowed the onslaught of suburbanization, and enclosed downtown Stockton within literal and figurative limits which separated a wealthy suburban population from the deprived rest of the city. The result of this ghettoization, Camille Norton points out, is "a warehouse for the criminalized poor" (Norton, 2000: 1), one that generates a particular configuration of masculine dispossession and that on film provides for characters as alienated as any found in the roughly contemporary work of an Antonioni or a Bertolucci.

Huston and his scriptwriter Leonard Gardner (a Stockton native, who also wrote the novel from which the film is adapted) were sensitive to the connection between the cityscape and the psychological conditions of the protagonists both in the novel and in the film. Norton writes that "Both Huston and Garnder [sic] grasped the relationship between Stockton's abject architecture -- its flophouses, bars, and migrant labour camps -- and the male body brutalized by labour and sport" (Norton, 2000: 2). In his autobiography, John Huston himself describes Stockton's Skid Row thus:

There were crummy little hotels; gaps between buildings like missing teeth; people -- blacks and whites -- standing around or sitting on orange crates; little gambling halls where they played for nickels and dimes. Many of the signs were in Chinese because the area had a large Chinese 
population. The police were very gentle with the derelicts. As long as they stayed within the sharply defined boundaries of the neighborhood, they could sleep in doorways, wine bottle in hand; if they wandered out, the police simply shooed them back. They were completely harmless, defeated men (Huston, 1994: 339).

One might ask, nonetheless, in what ways Fat City's appropriation of urban squalor as a reflection of, or metaphor for, existential nihilism is principally different from that of a host of other films that depict the contingencies of urbanity. After all, misgivings concerning life in the city are prevalent throughout the history of American culture, and it remains to establish whether, and in what sense, Huston's portrayal of Stockton differs from conventional manifestations of urban distrust. Discussing the national fascination with urban decay, Klein detects a historical continuity between what he calls "the cinematic image of the decayed city" and the "coverage of boozing and whoring in Irish Manhattan in the 1840s, with Dickens' complaints about New York, with Kipling's dire vision of Chicago" (Klein, 1998: 87). As a work of fiction, Fat City conceives of urban decline not as a condition eventually to be overcome by the slum dweller but as a lasting externalization of the plight of the characters that are products of the city. Thus, Huston's film refrains from partaking in the scenario -- enacted in so many films and novels -- in which the hero ritualistically rises above abominable and seemingly hopeless social conditions. The city for Huston thus becomes an extension of the protagonist, or vice versa, and not an antagonistic structure that the hero must conquer or escape from.

The politics of defeatism which is a parameter for Fat City serves to deglamourise the world of boxing and machismo in a way that few, if any, films in the genre have done before or after. ${ }^{(11)}$ Where Peckinpah's filmic dissections of the nature of violence and American masculinity typically suggest a curious ambiguity in which the phenomena he analyses are condemned and applauded at the same time, Huston's approach to the subject appears singularly critical. As Gaylyn Studlar has maintained, "Fat City refuses to celebrate a male world... Instead, the film's disturbing tensions suggest the very impossibility of the ideal based on the cult of the body even as it reveals the pernicious force still exerted by that necessarily aggressive ideal on economically marginalised, white working-class and minority men in late twentieth-century America" (Studlar, 1993: 179). "Fat City," Studlar goes on, "deviates in important ways from the formula of the classical Hollywood boxing films popular in the 1930s and 1940s. These films traditionally utilize the male body as the means of melodramatically revalidating American myths of aggressive masculinity" (Studlar, 1993: 181).(12) Equally significant, I would argue, is the way in which Huston's movie -- in its pursuit of defeatism -- is also markedly different from the boxing films which succeeded it, as for example Avildsen's Rocky (1976), Franco Zeffirelli's The Champ (1979) and Martin Scorsese's Raging Bull (1980). Even the director of Taxi Driver revels to some extent in an unabashed glorification of violent sports and a fetishization of the male body. Avildsen's and Zeffirelli's films are, in addition, permeated with a melodramatic sentimentality which is foreign to the aesthetic sensibility of Fat City. ${ }^{(13)}$

One reason for the film's refusal to engage in generic rhetoric is related to Huston's commitment to a sociological portrayal of Stockton's inner city milieu and its inhabitants. He is considerably less interested in a propagation of the fairytale-like success stories constitutive of so much Hollywood fare. Like Peckinpah in Junior Bonner, Huston willingly relinquishes the action-driven plot in order to achieve the desired effect. Hence, one might claim that the ostensible "themes" of the two films -- boxing and the rodeo -- really work as narrative pretexts for an exploration of other issues that are not so manifestly discernible on the surface level of the movies.

In a scene toward the end, Junior Bonner remarks that he has to "go down...[his] own road," stating thereby what can be conceived of as the defining aspect of the film. Although Junior has his closest family in Prescott, it is clear that it is the rodeo competition more than kinship that has brought him back. Junior Bonner is above all a drifter, a modern-day Western vagrant whose aimlessness and lack of a sense of spatial belonging define his identity. His uprootedness and desolation become all the more pronounced if one takes into account the fact that culturally and ideologically he is a stubborn anachronism. The town of Prescott, Arizona in the early 1970s is no more the Old West with which Junior Bonner identifies, and the Frontier Days Parade inadvertently makes a sheer mockery of the historical heritage. Douglas Pye aptly describes the rodeo procession thus: 
Peckinpah picks out the traditional Western figures -- the mountain man, Indians, pioneers in their wagon -- but in the procession these form only part of an extraordinary mixture -- a pipe band, vintage cars, commercial floats, motor cyclists. The treatment underlines the incongruity by cutting rapidly from one thing to another, creating bizarre juxtapositions, a muddle of disparate elements in which the traditional meanings of the rodeo have been all but lost (Pye, 1986: 59).

Despite the bustling rodeo iconography -- and despite Junior's eventually triumphant homecoming -- the world of Prescott represents a profoundly alienating experience. The primary incarnation of the antithesis of Junior's values is his own brother Curly, an industrious real estate developer who has bought their father's land for nothing and who proudly exclaims that mobile homes represent the future. Curly's commercial enterprise could not have been further removed from Junior's own ethics, which are resolutely founded on the values of the Old West: frontier individualism, independence and the freedom and room to roam the wide open spaces. "Curly's New West concept of the joys of 'total electric living' in model mobile homes," Doug McKinney points out, "does not celebrate the Old West beyond its commercial use" (McKinney, 1979: 135).

Perhaps not even in The Wild Bunch (1969) or The Ballad of Cable Hogue (1970) does Peckinpah's elegiac stance, as well as his resentment of the modern world, come forward so explicitly and so ironically. In The Wild Bunch, technological progress and cultural evolution (the "easternization" of the west) are rhetorically aligned with mass destruction; in The Ballad of Cable Hogue, the protagonist -- a quintessential "Western" individualist and recluse -- is run down by an automobile, one of the salient symbols of modernity. In Junior Bonner, the director stages the clash between the values of the Old and the New West spatially and architectonically. Two instances are thus particularly illustrative. Early in the film, as he is returning to his father Ace Bonner's ranch, Junior Bonner witnesses the demolition of the family house by bulldozers. The former home of the Bonner family must give way to the inevitability of suburbanization with all its demographic, social and aesthetic consequences. As a visual metaphor for the destruction of the past by the instruments of a ruthlessly advancing modernity, the sequence epitomizes the causes of Junior's estrangement and his existential malaise.

Filming this scene Peckinpah, quite revealingly, adopts a subjective point of view in order to emphasize the emotional impact the bulldozing of the house has on the protagonist. In the moment of destruction, however, Junior's glance is directed elsewhere and he misses the event. As he turns to gaze at the house, it is already demolished, but the following shots replay the action from his psychological point of view. A shot of Junior looking dejectedly at the result of the earthmover's work is followed by a slow motion insert in which the family dwelling is torn down again. These decelerated frames are then intercut with a shot of a photograph of Ace in the rodeo, two shots of the house undamaged, two shots of Ace riding a horse at the rodeo, and finally one shot of the mailbox being run over by a bulldozer. Stephen Prince claims that this sequence "shows Junior's obsessive psychological replaying of the loss of the house, and [that] it is loaded with emotionally significant images of Ace that demonstrate the multiple levels on which this event resonates for Junior" (Prince, 1998: 89). A similar permutation of different temporal segments is also found in the credit sequence, whose split screen techniques, Nigel Andrews points out, suture past and present in order to convey "the idea of a continuous, unchanging way of life" (Andrews, 1973: 74)

The second instance in which the filmmaker articulates his critique of the New West through the activation of purely environmental or spatial cues occurs before and during the City Parade. As part of the rodeo festival, the pageant features the paraphernalia, costumes and effects associated with the Old west, albeit in a commercialized, tacky fashion which is more pathetic than reverent. This transformation of western values from genuine, lived experience to cheap simulacra, is the surest sign of the irretrievable pastness of the old west. In Sydney Pollack's The Electric Horseman, similar sentiments resurface. Discussing the disneyfication of the rodeo as it is reborn as Las Vegas spectacle, the author of the following passage decries what the West has become in late $20^{\text {th }}$ century America:

Once, he [the main protagonist in Pollack's film] performed in rodeos, which offered audiences a theatrical and ritual re-enactment of the substance of the Old West that still had some connection to the social reality it depicted. Like gladiator games, they weren't merely "shows" but life-anddeath contests in which the subduing of nature that was once the essence of the West, was depicted 
by a genuine struggle. But now, like much else around him, Steele has become a themed (which is to say, falsified) version of himself, a character in Ampco's [a multi-billion dollar conglomerate] universe of reinvented reality (Sanes, 2000).

In Junior Bonner, the loss of the model -- which is the real West -- is implicitly mediated by the mise-enscene rather than explicitly, or dramatically, by dialogue or action. As Junior Bonner and Curly are clearly marked as polar representatives of the old and the new, so are their parents Elvira (Ida Lupino) and Ace (Robert Preston) embodiments of different ways of adjusting to their present moments. Elvira, who is not fascinated with the new in the same way as her son Curly is, manages to accommodate modernity and to cope with changing circumstances like accepting the selling of the ranch, and starting a new business. Ace, conversely, prepares to go to Australia, apparently to escape the encroachment of the new, and to seize another opportunity to continue his career as a prospector. The implication is obvious: for Ace, Australia represents the new frontier, there being none left in his home country. In ideological terms, Peckinpah juxtaposes the attitudes and the will to social and cultural acclimatization of two sets of character: the traditionalists (Ace/Junior Bonner) and the reformists Elvira/Curly, the maladjusted and the adjusted. A scene extending from the parade sequence humorously summarizes Ace and Junior Bonner's plight: as the two men ride away on one horse through the neighbourhood area, they are thrown off the animal by a clothes line they fail to see. Again, relying on uniformly cinematic cues, Peckinpah creates a situation whose subtly symbolic content economically presents a telling image of the domestication of the reckless.

Junior's condition comprises entrapment on the one hand, and movement on the other. The sense of estrangement from the new west -- Junior's impossible attachment to that which is irrevocably gone -- implies isolation and enclosure. Because he is essentially a drifter, he is in constant movement, touring the rodeo circuit from town to town. His state of entrapment, paradoxically, induces not stasis but movement, and his life of permanent drift increases his sense of alienation and entrapment, because it does not lead anywhere. This description accords well with Leo Charney's thesis that "in modernity all that is stable drifts into motion" (Charney, 1998: 6). ${ }^{(14)}$ In this respect, Junior Bonner's values and lifestyle echo Madame Ranevskaya's words in Anton Chekhov's The Cherry Orchard; "you do nothing, fate simply tosses you from place to place." Junior Bonner's conception of temporality is also affected by his spatial fluctuations; in the scene with the bulldozers, as I have pointed out earlier, Junior "sees" the objects of the past where they no longer exist. In the very beginning of the film, images of long past rodeo activities linger on in his mind and usurp the space of the present, something which also recurs later in the narrative. Discussing the work of Proust, Charney describes modernity and drift in a manner that seems to apply to Junior's state of mind: "drift is not even and durational but studded with instantaneous flashes of consciousness and perception" (Charney, 1998: $11)$.

"You're just not the rider you was a few years back," a character responds when Junior Bonner tells him that he intends to ride the bull Sunshine in the rodeo contest. The sentence reads as an epigraph for both Peckinpah's film and Fat City. They both grapple with forms of masculinity curiously at odds with their surroundings, and the images that capture this feeling of displacement are suffused with a film aesthetic that refashions the bleak and abject (sub)urban locations into a poetry of rusty, frayed space. Although Junior Bonner and Billy Tully may not be the men they once were, they nevertheless maintain their values and integrity in the face of changing times and changing luck. This loner, the desolate, and by all accounts obsolete male, represents the quintessential Peckinpah hero as, among others, Nigel Andrews has pointed out (Andrews, 1973: 73). Dividing the director's protagonists into two types -- the individualist and the survivor -- Andrews asserts that Junior Bonner is the rare hero who manages to combine these determinations:

the individual, for Peckinpah, is the man who is loyal to his own beliefs and values rather than to those of an external regime or creed, and who is also, in the stricter sense of the word 'individual,' one who cannot be divided -- that is, he will not willingly bend from his beliefs in order to survive... In their various ways, Steve Judd in Guns in the Afternoon, Pike Bishop in The Wild Bunch, and the eponymous hero of The Ballad of Cable Hogue are all individuals, becoming anachronistic in their unwillingness to change, and dying significantly at the point of transition between an old age and a new (Andrews, 1973: 69).

Junior Bonner, however, does survive, which should indicate that he has adapted to the conditions of a new 
era, which, following Andrews' argument, should insinuate a sacrifice of a certain belief system. Andrews rejects such an interpretation, claiming that "the synthesis of individualism and survival...is not necessarily a moral fall from grace. Rather, it indicates the capacity of the characters, while remaining true to a central core of values, to adjust their life styles in order to maintain their equilibrium in an uncertain and treacherous age" (Andrews, 1973: 70). In contrast, the wild bunch in the film of the same name can hardly be said to maintain psychological balance as they go out in the most violent way imaginable. Borrowing a phrase from Richard T. Jameson, one could grasp the mentality of someone like Junior with reference to a notion of "survivalist sublimity" (Jameson, 1994: 203).

In Fat City, we encounter a protagonist who resembles Junior in many ways. Socially, he is an outsider, an outcast, just like the Peckinpah hero. Psychologically, he shares with Junior combined dispositions toward independence, solitude, lack of ambition, lack of illusion, restlessness and, above all, non-conformism. Both men are decidedly over the hill in their professional careers as boxer and rodeo rider, and although they both win their respective contests toward the end of each film, neither Junior Bonner nor Billy Tully are depicted as heroic victors. Tully's achievement in the ring is compromised by the fact that his opponent was seriously ill during the match, urinating blood in a scene preceding the fight. Moreover, Tully hardly realizes or acknowledges that he has defeated Lucero in the ring anyway, and the coda which follows indicates that his dreams of comeback most likely will give way to booze and despair. Junior, on the other hand, manages to stay on the bull Sunshine for more than eight seconds, which makes him a champion of the rodeo, thus preserving his reputation as an expert rider. His days as a rodeo prodigy are nonetheless numbered due to his age, and the familial frictions -- the demolition of the ranch, his brother's contrasting values, and the fact that his father is leaving the country -- narratively speaking diminish the scope of his accomplishment. Finally, he does not get the girl even though he emerges heroically from the fight, a plot manoeuvre which represents an equally heroic aberration from the traditional Hollywood formula.

It would be an exaggeration to insist that Junior Bonner and Fat City are remarkably plot-driven movies. As I have implied elsewhere, narration in both films proceeds at a leisurely pace, one in which the camera eye in its selection of and meditation upon the mise-en-scene commands the structure of the story. This aesthetic approach arguably owes more to environmental dissection than to diegetic thrust, which is a narrative preference additionally supported by both directors' flair for naturalistic, documentary detail and spatial verisimilitude. In Fat City, Huston's use of non-actors and natural light augments these qualities, as do his characters' vernacular speech and the frequent use of both deep focus, the long take and the long shot. In spite of its rapid editing and slow motion cinematography, Junior Bonner also charges its film spaces with a lively authenticity that foregrounds the visual environment as a major narrative agent. It appears as if the politics of desolation permeating these films is only communicable in visual terms delicately defined. The adherence of Huston's text to a poetics of naturalist topography, and its function in promoting the theme of the movie, is a quality appreciated also by Camille Norton, who writes that the filmic mediation of "an urban space like Stockton, California engenders an agonistic masculine body, a body that expresses the history of the American West in terms of decline, degradation, and the reopening of wounds" (Norton, 2000: 2).

It should not pass unnoticed that the relation between male desolation on the one hand, and urban abjectness on the other reappears as a thesis in David Fincher's Fight Club (1999). In this film, the infliction of violence and pain on the male body becomes an unlikely remedy for the alleviation of the existential emptiness that has overcome the protagonist. Equally significant is the form of the appropriated violence. In an era when violent destruction increasingly becomes the province of hyper sophisticated computer technology, the characters in Fight Club resort to raw and primitive fist combat. Unlike Billy Tully in Fat City, however, Jack -- the Edward Norton character in Fincher's film -- is a well off, white-collar middle class member with a spate of frustrations not wholly un-related to those of Billy Tully. Although Jack is sick of his job and wants to leave, and while Huston's protagonist has great trouble finding a job in the first place, both embody a kind of desolate, despairing masculinity which finds an outlet in forms of physical aggression; Tully in the ring, Jack in the highly informal fight club meetings of which he himself is the high priest. ${ }^{(15)}$

Whether the scene is Stockton, Prescott or Los Angeles, Fat City, Junior Bonner and Fight Club all indict modernity and materialism as oppressive forces that limit individual expression and pacify emotion. Importantly, an unwelcome corollary of the modern-materialistic compound is the escalating sense of aesthetic impoverishment that is so vividly presented in these films. The opening shots of Huston's movie eloquently 
underscores the dilapidated state of Stockton's centre. Shots of the cross-town freeway which -- in Norton's words, "made it possible to get around downtown Stockton without ever actually entering it," and which "erected an effective concrete barrier between the 'haves' and the 'have nots' and ushered in a new era of suburban construction" (Norton, 2000: 1) -- are soon followed by images of Tully in his cheap, dank and gloomy motel room. Norton further stresses the downtown area's status as "an urban space designed to contain the multiracial poor, the transient or seasonal laborers" (Norton, 2000: 3). Tully himself has severe difficulties finding work (even today's Stockton has an unemployment rate three to four times the national average), and his plans to make a comeback as a professional boxer are principally motivated by his antagonism toward the prospect of remaining an agricultural labourers. As the narration so pessimistically implies, his future does not seem to be much different from his current situation, an anticipation the protagonist purportedly acknowledges as he gazes out at the visitors in the café in the film's final sequences. Cinematically, this scene is coded as an instance of character revelation; in a sequence of subjective point-of-view shots -- of which there have been very few in the course of the preceding narrative -- Tully's realization is unprecedented and profound. As the scene unfolds the sound is eliminated and time stops for a few seconds. Lawrence Grobel thus reports the conception of the sequence, beginning with Huston asking

"Have you ever been at a party when for no reason everybody just stops? When all of a sudden it's all a tableau; you're alone in eternity for a moment? When Stacy turns around, I want everybody to just stop what they're doing." "Why, John?" Keach asked. "I have no idea," Huston answered. "Sometimes the devil just gets into me" "We can just freeze frame," Russ Saunders, the assistant director, suggested. "No, no, no," John said. "I want the cigarette smoke to continue going. I don’t want it to look like a stock frame. I just want everybody to stop" (In Grobel, 1989: 638).

Lesley Brill has suggested that this moment in the narrative collapses the distinction between interior and exterior reality, fusing the subjective and the objective in an interlocking framework where the promise of revelation eventually seems to succumb to drunken opacity (Brill, 1997: 196). Despite the downcast atmosphere discharged from the last images of both Fat City and Junior Bonner, however, these discourses on defeatism affirm rather than renounce the probity of the main characters. Huston's and Peckinpah's accomplishment in these films thus becomes an articulate realization of Baudelaire's advice to artists to "seize upon nobility wherever it was to be found, even in the mire".

"Abject Topographies: Images of Male Desolation in Fat City and Junior Bonner" (Paper delivered at the $25^{\text {th }}$ American Studies Seminar "The Country and the City," Telemark University College, September 2000).

\section{Notes}

1. The film's title is slang for "making it." In the 1994 edition of the Random House Historical Dictionary of American Slang, the meaning is specified as "The condition of being extremely well off or having a superior advantage."

2. One critic retrospectively points out that at the 1972 Cannes festival, the film "occasioned Huston's first chorus of raves since the high Fifties" (Jameson 82).

3. As Axel Madsen points out, Fat City was "another of his [Huston's] works to have found vindication in history rather than the box office (3).

4. David Weddle partly blames the marketing of the movie for the scarce attention it received in the press and among the regular movie-going public (432). Since Peckinpah's film was treated as simply another Steve McQueen vehicle, it was mass released to hundreds of theatres at the same time, with the result that it was quickly removed from the program. This was against the intention of the director, who wanted to release the film in only a few select theatres in New York and Los Angeles first, and then let it build a reputation before it was distributed in more theatres across the country. Three years previously, The Wild Bunch had suffered from the same miscalculation. The reviews in Time and Newsweek were hostile, despite the fact that they were among the few journals that gave a positive evaluation of Straw Dogs. However, Junior Bonner was received warmly in the New York Times, the New York Post and The Daily News. William S. Pechter 
in Commentary wrote: "Junior Bonner provokes me to wonder whether anyone making narrative films has ever edited film more beautifully than Peckinpah (In Weddle 433).

5. The compositions of Huston's cinematographer, Conrad Hall, have been noted for their cinema vérité-like quality (McCarty 179).

6. Camille Norton has claimed that Fat City negotiates "the American quest as an allegory of masculine failure" .

7. Gaylyn Studlar traces the cultural significance of boxing as an emblem of American masculinity back to the 1890s, when athleticism came to represent a way of "revalidating male identity in the face of a perceived 'feminization' of American Culture" (178).

8. Peckinpah began shooting the film in and around the actual Frontier Days Rodeo on June 30, 1971, and finished on August 17, having exceeded the budget by $1 \$$ (Weddle 431). The film was edited by Bob Wolfe and Frank Santillo, and spent ten months in post-production. 9. Carringer's assertion that "poststructural theory has decimated any unshakable belief in the splendour of movie realism" appears to me to be generally correct, although André Bazin's theory of realism and space might still be salvageable on an intra-filmic level (as opposed to a film-reality level). 10. Consider for instance Richard T. Jameson's statement that "Huston's Stockton exists so wholecloth onscreen we think we're witness to an available reality instead of a cunning interpretation of that reality" (In Cooper 84). The film's insistence on verisimilitude, however, is also a cause of critical attack. In his article "How Not to Film a Novel" Charles Thomas Samuels asserts that Huston's rendition of Gardner's novel fails because it favours documentation at the expense of explanation (148).

11. It might be worth noting that as a film about boxing, Fat City has both autobiographical and literary precursors. Having discontinued his career as a ranking lightweight boxer in California, Huston went on to write two short stories based on his experience in the ring. "Fool" and "Figures of Fighting Men" appeared in H.L. Mencken's American Mercury.

12. Here Studlar and Desser have in mind films like Robert Rossen's Body and Soul (1947). Other titles with a similar subject matter include Winner Take All (Roy Del Ruth 1932), Palooka (Benjamin Stoloff 1934), Ringside Maisie (Edwin L. Marin 1941), The Champion (Mark Robson 1949), Somebody Up There Likes Me (Robert Wise 1956) and Requiem for a Heavyweight (Ralph Nelson 1962).

13. Huston's film style has sometimes been attacked its lack of a distinct visual approach. In his comprehensive though almost infamous book The American Cinema: Directors and Directions 1929-1968 (1968), Andrew Sarris -- one of the most distinguished film critics of the 1950s and 1960s -- ranks Huston under the heading "Less than meets the eye." "Unfortunately," Sarris writes, "Huston, unlike [Howard] Hawks, does not believe sufficiently in the action ethos to enjoy action for its own sake" (158). According to Studlar, however, Sarris might have entertained other motives for dismissing Huston for his seemingly unobtrusive style: "Sarris' remarks also suggest that Huston did not present a sufficiently positive model of masculinity compared to other specialists of homo-social Hollywood cinema such as Hawks and [Raoul] Walsh" (183).

14. Charney's axiom is indebted to Alfred Wegener's theory of drift from 1915.

15. Significantly, Fight Club differs radically from the two 1970s films not only in its style and tone, but also in its refusal to acknowledge the entrapments of seemingly inescapable social conditions. In its insurgent anti-consumerist ideology, Fincher's film unsubmissively welcomes illusion and utopia as alternatives to the meaninglessness generated by the contemporary spiritual impasse. In the Huston and Peckinpah films, on the other hand, the characters' acceptance of a given social reality emerges as the narratives' fundamental insight. Contrary to Fincher's movie, therefore, Fat City and Junior Bonner are tales not so much of disillusion as of non-illusion; particularly in the former there does not seem to have been any illusions to begin with. The characters of Tully and Junior are fully aware both of their predicament and of the futility of thinking that the situation will improve. One might object to such a filmic attitude as highly suggestive of a pacifying determinism; notwithstanding, the salient point with respect to characterization in Huston and Peckinpah is that both filmmakers emphasize the irrepressible humanity of their protagonists despite the hopelessness of their condition. Scott Hammen corroborates this impression when he writes that in Fat City, 
the director portrays his characters "without a trace of condescension;" projecting onto them a "strangely noble sense of heroism" (124). Similarly, Lesley Brill applauds Huston for his "refusal to pass judgments" on the protagonists (191). This attitude, I suggest, reveals a cynical humanism not unlike that encountered in the later films of John Ford.

\section{References}

Andrews, Nigel. (1972) Review of Junior Bonner, Sight and Sound 41 (4), 230.

"Sam Peckinpah. The survivor and the individual." Sight and Sound 42 (2), (Spring 1973), 69-74.

Brill, Lesley. John Huston's Filmmaking. Cambridge: Cambridge UP, 1997. Carroll, Kathleen. Review of Junior Bonner. Filmfacts 15 (17), 1972, 412-413.

Charney, Leo. Empty Moments. Cinema, Modernity, and Drift. Durham: Duke UP, 1998.

Cook, Pam. Masculinity in Crisis? Tragedy and Identification in Raging Bull, Screen: Incorpo-rating Screen Education 23, 1982, 39-46.

Dukore, Bernard F. Sam Peckinpah's Feature Films. Urbana: U of Illinois, 1999.

Ebert, Roger. Review of Junior Bonner, Filmfacts 15 (17), 1972, 412.

Grobel, Lawrence. The Hustons. New York: Charles Scribner's Sons, 1989.

Hammen, Scott. John Huston. Boston: Twayne Publishers, 1985.

Huston, John. An Open Book. New York: Da Capo Publishers, 1994.

Fat City, in Gerald Pratley, The Cinema of John Huston. South Brunswick: A.S. Barnes \& Company, 1977.

Jameson, Richard T. Fat City, in Stephen Cooper (ed.), Perspectives on John Huston. New York: G.K. Hall \& Comp, 1994.

Klein, Norman M. Staging Murders: "The Social Imaginary, Film, and the City", Wide Angle. A Quarterly Journal of Film History, Theory, Criticism and Practice 20 (3) (July 1998), 84-96.

Madsen, Axel. John Huston. Garden City, NY: Doubleday \& Company, Inc., 1978.

Marill, Alvin H. Review of Junior Bonner, Films in Review 23, (Aug-Sept. 1972), 435.

Matheou, Demetrios. Laying the Groundwork, Sight and Sound, 9 (10), 1999, 28-29.

McCarty, John. The Films of John Huston. Secaucus, New Jersey: Citadel P. McKinney, Doug (1979) Sam Peckinpah. Boston: Twayne Publishers, 1987.

Milne, Tom. Junior Bonner, in Claus Krohn Holm, Mette Weisberg \& Niels Weisberg. (eds.), Westerns: Theory and Analysis. Copenhagen: Gjellerup \& Gad, 1986.

Norton, Camille. Abject Architecture and the Male Body in John Huston's Fat City, Conference paper for The American Culture Association / Popular Culture Association. New Orleans, 2000.

Parrill, William. Heroes' Twilight: The Films of Sam Peckinpah. Minneapolis: Alpha Editions, 1980.

Prince, Stephen. Savage Cinema. Sam Peckinpah and the Rise of Ultraviolent Movies, Austin: U of Texas, 1998.

P. Pye, Douglas. Junior Bonner, in Claus Krohn Holm, Mette Weisberg \& Niels Weisberg. (eds.), Westerns: Theory and Analysis. Copenhagen: Gjellerup \& Gad, 1986.

Samuels, Charles Thomas. "How Not to Film a Novel," The American Scholar. A Quarterly For the Independent Thinker (1), 1972, 148-154.

Sarris, Andrew. The American Cinema. Directors and Directions 1929-1968. New York: E.P. Dutton, 1968 
Studlar, Gaylyn. Shadowboxing: Fat City and the Malaise of Masculinity, in Gaylyn Studlar \& David Desser (eds.), Reflections in a Male Eye. John Huston and the American Experience. Washington: Smithsonian Institute, 1993.

Thomas, Kevin. Review of Junior Bonner, Filmfacts 15 (17), 1972, 411-412.

Weddle, David. If they Move...Kill 'Em! The Life and Times of Sam Peckinpah. New York: Grove Press, 1994.

\section{Websites}

Sanes, Ken. The Electric Horseman: Escape from the Garden of Image Commodities. http://www.transparencynow.com/horseman.htm, August 2000.

\section{Author Information}

Asbjørn GRØNSTAD is Professor of visual culture in the Department of Information Science and Media Studies, University of Bergen. His latest publications are Transfigurations: Violence, Death and Masculinity in American Cinema (Amsterdam University Press, 2008) and Coverscaping: The Art of the Album Cover, co-edited with Øyvind Vågnes (forthcoming). 